Original Research Paper

\title{
Measuring three Demarketing Cases using Statistical Methods
}

\author{
Eunice Lebogang Sesale, Mantepu Tshepo Mase Tshaba, \\ Tshepo Matsose, Gezani Richman Miyambu and Solly Matshonisa Seeletse \\ Department of Statistics and Operations Research, \\ Sefako Makgatho Health Sciences University, PO Box 107, MEDUNSA, 0204, Gauteng Province, South Africa
}

Article history

Received: 30-09-2016

Revised: 08-01-2017

Accepted: 13-01-2017

Corresponding Author: Solly Matshonisa Seeletse Department of Statistics and Operations Research,Sefako Makgatho Health Sciences University, PO Box 107, MEDUNSA, 0204, Gauteng

Province, South Africa

Email: solly.seeletse@smu.ac.za

\begin{abstract}
This paper applies statistical measures to illustrate effects of 'demarketing' in three case studies. The first case involves a leading Internet café which had recently lost customers to rivals in the same trading environment. The second one involves a reputable Chicken farm that had also lost many clients. The third one involves a Catering services company that had lost some of its customers. The three cases are respectively labelled 'Int café', 'Chicken farm' and 'Catering services'. Despite these being dissimilar cases, some similarities occurred with the way they lost favor with their clients. The paper calculates and compares the demarketing effects in the three cases using the measures.
\end{abstract}

Keywords: ANOVA, CV, Demarketing, Percentage

\section{Introduction}

Habits and behaviors of consumption influence marketing perceptions and purchasing response. Shrewd marketers depend on these traits to increase individual perceptions to improve consumer behaviors. Alsamydai (2015) points out that 'demarketing' is a strategy usually applied for this purpose. Demarketing is an effort to decrease consuming tendencies towards a product. An earlier study conducted by Seeletse (2016) showed that demarketing can be used to reduce customers and even to displace customers from competitors. Due to small data sets used in that study, the impression and results obtained were not tested using statistical inference. This paper is a follow up based on adequate data sets.

\section{Demarketing Purpose}

The purpose of demarketing is to build a strong quality image in the long run at the cost of current sales (Zhao, 2000). Thus, demarketing is optimal only when the relative mass of late adopters is sufficiently high. In addition, demarketing is worthwhile only if buyers are sufficiently uncertain about quality. Specifically, if buyers are very pessimistic, the seller should choose full marketing to maximize the chance of achieving stellar first-period sales to prove its high quality to late adopters. If buyers are very optimistic about quality, they will have high willingness to pay anyway. Consequently, there will be little room for improvement in quality perception and thus little return to demarketing. In this case, the seller should again choose full marketing and maximize expected sales volume.

Two essential conditions giving rise to demarketing as an optimal seller strategy are evident sales and noticeable marketing efforts (Stock and Balachander, 2005). If buyers could not access past sales as a quality indication, the seller would in each period select the highest possible level of costless marketing efforts to raise buyer interest and maximize expected profits. The demarketing value fatefully depends on its discernibility to buyers. It must be able to serve as a conspicuous excuse of mediocre sales to influence beliefs. The rationale behind demarketing continues to hold as long as buyers observe informative signals of past sales and marketing efforts.

The other technical condition that the exact buyer interest level should be discreet to ensuing buyers, as they can deduce quality by converting the rate between buyer interest and sales (Horstmann and MacDonald, 2003). Evidently, a broad condition for demarketing is that late adopters cannot completely study the effect of marketing on sales in order to seamlessly understand quality. If demarketing loses influence on beliefs, the seller will again maximize marketing efforts. This technical condition should hold in many circumstances due to the personal and often idiosyncratic nature of buyer interest.

Goldstein (2009) observed that if product sales are openly visible, they may affect consumers' quality beliefs. Also, if marketing efforts are exposed, they may further change consumers' quality inference process. 
Consequently, demarketing can benefit a seller by inducing buyers to infer better quality from the sales quantities.

According to Berger and Le Mens(2009), demarketing is about finding the segments whose needs cannot be met with the current offering. It also ensuresthat they do not self-select themselves to be customers. It is fundamentally about getting the right clientblend whose expectations can be satisfied and needs served by an existing product. Hence, demarketing deliberately destroys marketing efforts to depress demand even if such efforts are costless. Iyer and Kuksov (2010) view demarketing as an opportunity to make choices by turning away the improperclientsto preventchasing the proper ones. The benefits of demarketing, according to several authors (Bagwell, 2007; Boseet al., 2006; Ho and Zheng, 2004; Kopalle and Lehmann, 2006), include that:

- Only the customers who prefer a market for manageable reasons that are controllable and deliverable can remain clients

- Sudden uptake of customers who would disappear immediately after appearing is not likely to happen

- The demarketing firm will not acquire clients whose lifestyle, taste or ability to pay is momentary or impulsive

- Demarketing firms are not compelled or tempted to change their product mix to serve the clients who should not be in the market segments

- There will not be dissatisfied customers who breed substantial negative word of mouth marketing

- The core clients will not be discouraged by the presence of wrong clients

The main purpose of this paper was to statistically compare the effect of demarketing on three cases, one involving Internet café, the other involving Chicken farm and the last one involving a Catering.

\section{Statistical Methods}

\section{Coefficient of Variation}

The population Coefficient of Variation (CV) is a standardized measure of dispersion of a probability distribution defined as the ratio of the standard deviation $\sigma$ to the mean $\mu$ (Everitt, 1998). The mathematical equation of $\mathrm{CV}$ is:

$$
C V=\frac{\sigma}{\mu}
$$

The CV has many applications in various scientific fields. According to Reedet al. (2002), the CV is commonly applied in analytical chemistry to express the precision and repeatability of an assay. It is also normally applicable in fields of engineering and physics for quality assurance activities, as well as the analysis of variance (ANOVA). Broverman (2001) informs that the $\mathrm{CV}$ is known as the unitized risk when it is applied in actuarial science. It is used to measure efficiency in signal processing where it is called signal-to-noise ratio (Sawant and Mohan, 2011; Schiffet al., 2014). The CV, according to Champernowne and Cowell (1999), is also highly useful in measuring economic inequality and distribution of incomes.

The CV is also common in applied probability fields such as renewal theory, queueing theory and reliability theory in which the exponential distribution is often more important than the normal distribution (Eisenberg, 2015; Sokal and Rohlf, 1995). In exponential distribution the standard deviation equals the mean and so $\mathrm{CV}=1$. Distributions such as the Erlang distribution have $\mathrm{CV}<1$ and are considered low-variance, while those such as hyper-geometric that have $\mathrm{CV}>1$ are considered high-variance.

Equation 1 is a population parameter, which may be estimated by substituting the parameters with their estimates. This occurs when only a data sample from a population is available (Freedman,2005). The CV is then estimated by the sample coefficient of variation $(\mathrm{cv})$ using the ratio of the sample standard deviation sto the sample mean $\bar{x}$ given by:

$c v=\frac{s}{\bar{x}}$

The CV is computed only for data measured on a ratio scale because the measurements take only nonnegative values and may not have any meaning on an interval scale. A weakness of the mean and standard deviation is that they are easily influenced by outliers and influential observations (Campano and Salvatore, 2006; Julious and Debarnot, 2000). A robust possibility is the quartile coefficient of dispersion (also known as the hinge $H$ ) defined as the interquartile range $I R$ divided by the average of quartiles $\bar{Q}$, given by:

$H=\frac{I R}{\bar{Q}}$

where:

$$
I R=Q_{3}-Q_{1}
$$

where:

$Q_{i}=\frac{i}{4}(n+1)^{\text {th }}$ score $; \quad i=1,2,3$ 
and:

$$
\bar{Q}=\frac{1}{3} \sum_{i=1}^{3} Q_{i}
$$

\section{Frequency Analysis}

A frequency analysis summarizes data by depicting the number of times values occur using a table (Dodge, 2003; Hinkelmann and Kempthorne, 2008). Such a tablehas at least two separate columns.One column shows intervals where the number of intervals is determined by the range in data values.Another column has frequencies of the values within the intervals. The analysis explores data with reference to a frequency table.

\section{Descriptive Analysis}

Descriptive statistics are statistics that quantitatively summarize features of data collected (Nicholas, 2006; Wichura, 2006). They review a sample, not the population that the sample represents. This generally means that descriptive statistics are not developed on the basis of probability theory. When data analyses draw main conclusions using inferential statistics, descriptive statistics are also presented (Howell, 2002).

\section{Pearson Correlation}

Correlation is a broad class of statistical relationships involving dependence, but commonly used to refer to the extent to which two variables have a linear relationship with each other (Székely et al., 2007). Correlations are useful in predicting relationships that are exploited in practice. Formally, dependenceis when random variables fail to satisfy a mathematical condition of probabilistic independence. Technically, correlation is any of several specialized types of relationships between mean values. The correlation coefficients, often denoted by $\rho$ or $r$, measure the degree of correlation. A common one is the Pearsoncorrelation coefficient, which, according to Székely and Rizzo (2009), is sensitive to a linear relationship between two variables.

\section{ANOVA}

ANOVA is a group of statistical models to analyze the differences among group means and their associated procedures (Cox, 2006; Gelman, 2008). In the ANOVA setting, the observed variance in a particular variable is partitioned into components associated with different sources of variation. According to Gelman (2005), ANOVA tests whether or not the means of several groups are equal, generalizing the $t$-test to more than two groups.

\section{Percentages}

A percentageis a dimensionless number or ratio articulated as a fraction of 100 and symbolised by the percent sign "\%" (Bennett and Briggs, 2005; Tabachnick and Fidell, 2007). It is used for comparison and is quite useful when compared items differ in units.

\section{Methodology}

\section{Research Design}

This paper evaluated losses of followers as a result of demarketing.

\section{Data Collection Tool}

The empirical part used questionnaires to collect data. A five-point Likert scale was used for the items investigated, with dimensions ' 1 ' = 'agree strongly', ' 2 ' = 'agree', ' 3 ' = 'never happened', '4' = 'disagree' and '5' $=$ 'disagree strongly' (Alsamydai, 2015).

\section{Study Population}

Three strata forming the study population were used for this paper. These three strata cases were Internet café, Chicken farm and Catering services.

\section{Sample}

The sample was selected from the strata (three cases) and therefore, a stratified sampling method was used.

\section{Data Collection}

Study questionnaires were distributed to the respondents for soliciting responses. Six hundred hard copy questionnaires were prepared and two hundred were distributed to strata members in each case. Also, electronic circulations were made to ensure that there were no questionnaire shortages to likely respondents.

\section{Data Analysis}

Scaling is vital in research (Malhotra et al., 2004). Furthermore, the measure from the Likert scale was measured based on the total of five (5). Statistical methods were used to analyze the data. These methods were frequency analysis, descriptive analysis, CV, Pearson correlation matrix, the t-test and percentages.

\section{Results}

\section{Participants}

A total of 685 respondents participated in the study. They were distributed as 183 Internet café respondents, 267 Chicken farming ones and 235 Catering services ones. The Table 1 displays the results. 


\section{Measurement Results}

The statistical measures appear in the nexttable.

Figure 1 shows that there were fewer respondents who had not been influenced by demarketing. This is demonstrated by low measures at 'ones' and 'twos'. Those at 'fours' were in the majority. The seriousness of the influence is shown by existences of demarketing at maximum level 'fives', or $100 \%$. The total of 'fours' and 'fives' exceeds those that were not influenced. The modal occurrences were at $80 \%$ (fours) for all the strata at individual (café, farm and catering), as well as at combined levels.

Using the proportions and heights of the bars, the Chicken farming trade was affected the most by demarketing. It was followed by Catering services and then by Internet café trade. Internet café was not displaced a lot at maximum level 'fives'. These apparent discrepancies are tried formally using the ANOVA, which tests if on average, the three means are equal.

The hypothesis on which the ANOVA table is based is that the population means of the three variables of focus (Internet café, Chicken farm and Catering services trades) are equal. This is to compare if the influences of demarketing in the trades were the same. Table 2 shows that the observed test statistic given by $F(F=0.78)$ is lower than the critical $\mathrm{F}(\mathrm{F}=3.885)$ value. The hypothesis of equality cannot be rejected and this leaves no doubt that the demarketing influence was equally highly effective in the three cases.

Table 3 shows that the three variables are pairwise positively correlated. Chicken farming and Internet café are just highly marginally correlated and so is Internet café and Catering services. Chicken farming and Catering services are highly correlated. This is despite the fact that these variables are not causally related,but are fundamentally independent of each other.

\section{Robust Measures}

Before applying robust measures in Table 1, Chicken farming indicated to be most stable trade with smallest $c v=0.3695$. Then it was followed byCatering serviceswith $c v=0.4183$. Lastly, Internet café was the most unstable with $c v=0.6705$. By using the hinge in dealing with possible influences of outliers, Chicken farming is still the most stable trade with $H=0.6$, followed by Internet café with $H=0.667$ and then lastly by Catering services with $H=0.8571$.

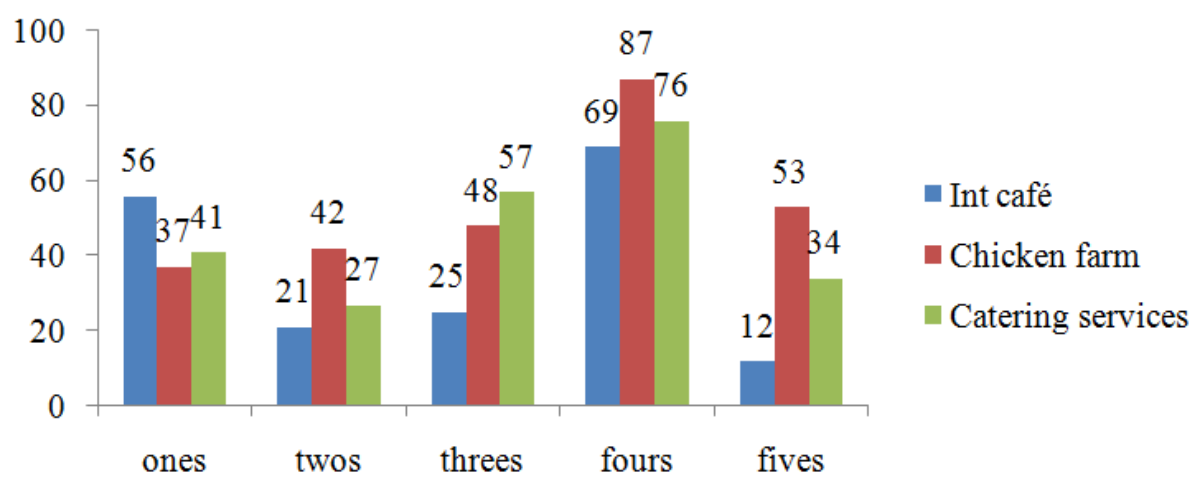

Fig. 1. Comparison of category responses

Table 1. Frequency and descriptive analyses

\begin{tabular}{llll}
\hline Frequency & Int café & Chicken farm & Catering services \\
\hline Ones & 56 & 37 & 41 \\
Twos & 21 & 42 & 27 \\
Threes & 25 & 48 & 57 \\
Fours & 69 & 87 & 76 \\
Fives & 12 & 53 & 34 \\
Mean & 36.60 & 53.40 & 47.00 \\
Stddev & 24.5418 & 19.7307 & 19.6596 \\
cv & 0.6705 & 0.3695 & 0.4183 \\
$\mathrm{Q}_{1}$ & 1 & 2 & 2 \\
$\mathrm{Q}_{2}$ & 3 & 4 & 3 \\
$\mathrm{Q}_{3}$ & 3 & 4 & 4 \\
$\mathrm{IR}$ & 2 & 2 & 2 \\
$\bar{Q}$ & $7 / 3$ & $10 / 3$ & 3 \\
$\mathrm{H}$ & $6 / 7(0.8571)$ & $6 / 10(0.6)$ & $2 / 3(0.667)$ \\
\hline
\end{tabular}




\begin{tabular}{lllllll} 
Table 2. ANOVA & \multicolumn{1}{l}{} & & \\
\hline Source of variation & SS & df & MS & F & P-value & F crit \\
\hline Between Groups & 718.933 & 2 & 359.47 & 0.78 & 0.479 & 3.885 \\
Within Groups & 5512.4 & 12 & 459.37 & & & \\
Total & 6231.333 & 14 & & & & \\
\hline
\end{tabular}

Table 3. Correlation matrix

\begin{tabular}{llll}
\hline & Int café & Chicken farm & Catering services \\
\hline Int café & 1 & & \\
Chicken farm & 0.527 & 1 & 1 \\
Catering services & 0.694 & 0.807 & 1 \\
\hline
\end{tabular}

\section{Discussion}

The effects of demarketing on the three trades were numerically different. The Chicken farm trade showed to be mostly affected by demarketing, which gave the impression that most customers left the Chicken farming dealings than other trades. The Internet café was giving the impression that it was also affected by demarketing, but at the least effect compared to the other two trades. The ANOVA tests, on the other hand, showed that when considered in total, there were no significant discrepancies in the way these trades were affected by demarketing.

Statistical tests confirm that demarketing reduces the market and can also displace the customers from one trade to the other. The three trades lost customers to competitors. From a statistical viewpoint, the trades were dethroned by demarketing significantly alike.

\section{Recommendations and Conclusion}

\section{Recommendation}

The marketing strategies should:

- Sellers should incorporate demarketing towards competitors in order to lure and displace customers from competitors

- They should use demarketing to strategically manage buyers' quality perceptions by making marketing efforts visible

- They should use demarketing to benefit a seller by inducing buyers to deduce superior quality from the same sales levels

- They should ensure that internal structures do not have detrimental effects of demarketing to scare customers

\section{Conclusion}

Demarketing can affect any company and in large scales. Also, the extent of effect does not depend on the company type as the trades used in empirical studies were all different and showed to be affected equally and largely.

\section{Acknowledgement}

The authors are grateful to the respondents and data collectors in the study, who are anonymous.

\section{Funding Information}

The Department of Statistics and Operations Research funded the manuscript activities.

\section{Authors' Contributions}

Eunice Lebogang Sesale: Suggested statistical tests on previous work done and the compilation of the work as a journal manuscript.

Mantepu Tshepo Mase Tshaba: Supervised the study and the activities, including suggesting the methods for measuring the effects of demarketing.

Tshepo Matsose: Provided robust approaches based on her studies on 'Biases from poor data analyses'.

Gezani Richman Miyambu: Introduced the hinge statistic for robust analysis.

Solly Matshonisa Seeletse: Advised on various aspects of this paper and identified AJAS for this paper.

\section{Ethics}

The study benefitted from primary data, but there were no identification of companies or people. The ideas on 'demarketing strategies' were shared with the company representatives as a warning and educative for future positioning.

\section{References}

Alsamydai, M.J., 2015. The impact of ostensible demarketing strategy on improving product reputation in customer's minds. Int. Rev. Manage. Bus. Res., 4: 973-988.

Bagwell, K., 2007. The Economic Analysis of Advertising. In: Handbook of Industrial Organization, Armstrong, M. and R. Porter (Eds.), Elsevier, Amsterdam, ISBN-10: 008055184X, pp: 1701-1844. 
Bennett, J.O. and W.L. Briggs, 2005. Using and Understanding Mathematics: A Quantitative Reasoning Approach. 3rd Edn., Pearson Addison Wesley, Boston, ISBN-10: 0321227743, pp: 832.

Berger, J. and G. Le Mens, 2009. How adoption speed affects the abandonment of cultural tastes. Proc. National Acad. Sci., 106: 8146-8150. DOI: $10.1073 /$ pnas.0812647106

Bose, S., G. Orosel, M. Ottaviani and L. Vesterlund 2006. Dynamic monopoly pricing and herding. RAND J. Econom., 37: 910-928. DOI: $10.1111 / \mathrm{j} .1756-2171.2006 . t b 00063 . \mathrm{x}$

Broverman, S.A., 2001. Actex study manual, Course 1 examination of the Society of Actuaries, Exam 1 of the Casualty Actuarial Society. 1st Edn., Actex Publications, Winsted, ISBN-10: 1566984017.

Campano, F. and D. Salvatore, 2006. Income Distribution: Includes CD. Oxford University Press.

Champernowne, D.G. and F.A. Cowell, 1999. Economic inequality and income distribution. Cambridge University Press.

Cox, D.R., 2006. Principles of Statistical Inference. 1st Edn., Cambridge University Press, New York, ISBN-10: 0521685672, pp: 219.

Dodge, Y., 2003. The Oxford Dictionary of Statistical Terms. 1st Edn., Oxford University Press, London, ISBN-10: 0198509944, pp: 498.

Eisenberg, D., 2015. Improving qPCR telomere length assays: Controlling for well position effects increases statistical power. Am. J. Hum. Biol., 27: 570-575. DOI: 10.1002/ajhb.22690

Everitt, B.S., 1998. Cambridge Dictionary of Statistics. 1st Edn., Cambridge University Press, Cambridge, ISBN-10: 0521593468, pp: 368.

Freedman, D.A., 2005. Statistical Models: Theory and Practice. 1st Edn., Cambridge University Press, Cambridge, ISBN-10: 0521854830, pp: 414.

Gelman, A., 2005. Analysis of variance? Why it is more important than ever. Ann. Stat., 33: 1-53. DOI: $10.1214 / 009053604000001048$

Gelman, A., 2008. Analysis of Variance. In: The New Palgrave Dictionary of Economics, Durlauf, S. and L.E. Blume (Eds.), Palgrave Macmillan UK, Houndmills, ISBN-10: 0333786769, pp: 7300.

Goldstein, P., 2009. Star Trek' and the Real Art of Movie Marketing: Managing Expectations. The Los Angeles Times.

Hinkelmann, K. and O. Kempthorne, 2008. Design and analysis of experiments. 7th Edn., John Wiley \& Sons, Hoboken, ISBN-10: 0470128666, pp: 680.

Ho, T.H. and Y.S. Zheng, 2004. Setting customer expectation in service delivery: An integrated marketing-operations perspective. Manage. Sci., 50: 479-488. DOI: $10.1287 / \mathrm{mnsc} .1040 .0170$
Horstmann, I.J. and G.M. MacDonald, 2003. Is advertising a signal of product quality? Evidence from the compact disc player market, 1983-1992. Int. J. Industrial Organizat., 21: 317-345. DOI: $10.1016 / \mathrm{S} 0167-7187(02) 00086-3$

Howell, D.C., 2002. Statistical Methods for Psychology. 5th Edn., Duxbury/Thomson Learning, Pacific Grove, ISBN-10: 053437770X, pp: 802.

Iyer, G. and D. Kuksov, 2010. Consumer feelings and equilibrium product quality. J. Econom. Manage. Strategy, 19: 137-168. DOI: $10.1111 /$ j.1530-9134.2009.00248.x

Julious, S.A. and C.A.M. Debarnot, 2000. Why are pharmacokinetic data summarized by arithmetic means? J. Biopharmaceutical Stat., 10: 55-71. DOI: $10.1081 /$ BIP-100101013

Kopalle, P.K. and D.R. Lehmann, 2006. Setting quality expectations when entering a market: What should the promise be? Market. Sci., 25: 8-24. DOI: $10.1287 / \mathrm{mksc} .1050 .0122$

Malhotra, N.K., S.S. Kim and J. Agarwal, 2004. Internet users' information privacy concerns (Iuipc): The construct, the scale and the causal model. Inf. Sys. Res.. 14: 107-117. DOI: 10.1287/isre.1040.0032

Nicholas, J., 2006. Descriptive statistics. Mathematics Learning Centre, University of Sydney, New South Wales.

Reed, J.F., F. Lynn and B.D. Meade, 2002. Use of coefficient of variation in assessing variability of quantitative assays, Clin. Diagn. Lab. Immunol., 9: 1235-1239. DOI: 10.1128/CDLI.9.6.1235-1239.2002

Sawant, S. and N. Mohan, 2011. FAQ: Issues with efficacy analysis of clinical trial data using SAS. Pharma SUG.

Schiff, M.H., J.S. Jaffe and B. Freundlich, 2014. Headto-head, randomised, crossover study of oral versus subcutaneous methotrexate in patients with rheumatoid arthritis: Drug-exposure limitations of oral methotrexate at doses $\geq 15 \mathrm{mg}$ may be overcome with subcutaneous administration. Ann. Rheum. Dis., 73: 1-3. PMID: 24728329

Seeletse, S.M., 2016. Demarketing strategy to develop perceived product reputation: Applications in three distinct environments. Prob. Perspect. Manage., 14: 230-235.

DOI: $10.21511 / \mathrm{ppm} .14(4-1) .2016 .12$

Sokal, R.R. and F.J. Rohlf, 1995. Biometry. 1st Edn., W. H. Freeman, New York, ISBN-10:0716724111, pp: 887.

Stock, A. and S. Balachander, 2005. The making of a "Hot Product": A signaling explanation of marketers' scarcity strategy. Manage. Sci., 51: 1181-1192. DOI: $10.1287 / \mathrm{mnsc} .1050 .0381$

Székely, G.J. and M.L. Rizzo, 2009. Brownian distance covariance. Ann. Applied Stat., 3: 1233-1303. 
Székely, G.J., M.L. Rizzo and N.K. Bakirov, 2007. Measuring and testing dependence by correlation of distances. Ann. Stat., 35: 2769-2794. DOI: $10.1214 / 009053607000000505$

Tabachnick, B.G. and L.S. Fidell, 2007. Using Multivariate Statistics. 5th Edn., Pearson/Allyn \& Bacon, Boston, ISBN-10: 0205459382, pp: 980.
Wichura, M.J., 2006. The Coordinate-Free Approach to Linear Models. 1st Edn., Cambridge University Press, New York, ISBN-10: 1139461044, pp: 199.

Zhao, H., 2000. Raising awareness and signaling quality to uninformed consumers: A price-advertising model. Market. Sci., 19: 390-396.

DOI: $10.1287 / \mathrm{mksc} .19 .4 .390 .11788$ 